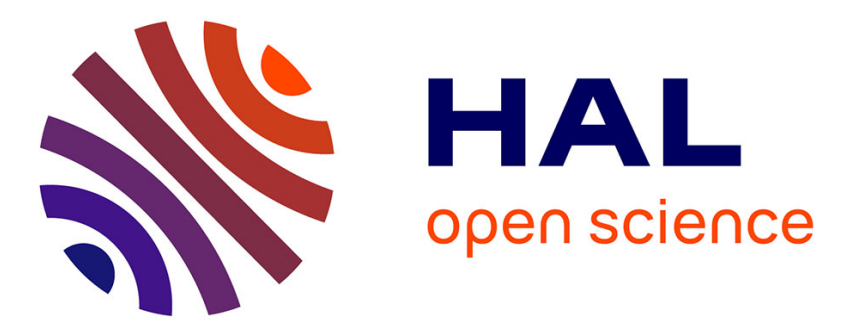

\title{
Anion Binding in Water Drives Structural Adaptation in an Azaphosphatrane-Functionalized Fe II 4 L 4 Tetrahedron
}

Dawei Zhang, Tanya K. Ronson, Jesús Mosquera, Alexandre Martinez, Laure Guy, Jonathan R. Nitschke

\section{To cite this version:}

Dawei Zhang, Tanya K. Ronson, Jesús Mosquera, Alexandre Martinez, Laure Guy, et al.. Anion Binding in Water Drives Structural Adaptation in an Azaphosphatrane-Functionalized Fe II 4 L 4 Tetrahedron. Journal of the American Chemical Society, 2017, 139 (19), pp.6574 - 6577. 10.1021/jacs.7b02950 . hal-01682780

\section{HAL Id: hal-01682780 https://hal.science/hal-01682780}

Submitted on 14 Apr 2018

HAL is a multi-disciplinary open access archive for the deposit and dissemination of scientific research documents, whether they are published or not. The documents may come from teaching and research institutions in France or abroad, or from public or private research centers.
L'archive ouverte pluridisciplinaire HAL, est destinée au dépôt et à la diffusion de documents scientifiques de niveau recherche, publiés ou non, émanant des établissements d'enseignement et de recherche français ou étrangers, des laboratoires publics ou privés. 


\title{
Anion Binding in Water Drives Structural Adaptation in an Azaphosphatrane-Functionalized $\mathrm{Fe}_{4}{ }_{4} \mathrm{~L}_{4}$ Tetrahedron
}

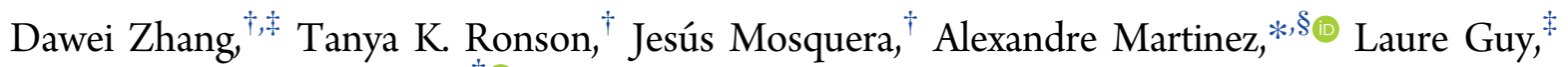 \\ and Jonathan R. Nitschke*,†] \\ ${ }^{\dagger}$ Department of Chemistry, University of Cambridge, Lensfield Road, Cambridge CB2 1EW, United Kingdom \\ ${ }^{\ddagger}$ Laboratoire de Chimie, École Normale Supérieure de Lyon, CNRS, UCBL, 46 Allée d’Italie, F-69364 Lyon, France \\ ${ }^{\S}$ Aix Marseille Univ, CNRS, Centrale Marseille, iSm2, Marseille, France
}

\section{Supporting Information}

ABSTRACT: Anion-templated aqueous self-assembly resulted in the formation of an endohedrally functionalized $\mathrm{Fe}^{\mathrm{II}}{ }_{4} \mathrm{~L}_{4}$ tetrahedron from azaphosphatrane-based subcomponents. This new water-soluble cage is flexible and able to encapsulate anions with volumes ranging from 35 to 219 $\AA^{3}$ via hydrogen bonding and electrostatic interactions. It structurally adapts in response to the size and shape of the template anions, dynamically adopting a conformation either where all four azaphosphatrane ${ }^{+} \mathrm{P}-\mathrm{H}$ vectors point inward, or else where one points outward and the other three inward. The two cage isomers can coexist in solution and interconvert. A shape memory phenomenon was observed during guest displacement because guest exchange occurs more rapidly than structural reconfiguration.

Celf-assembly is an efficient tool for the construction of diverse $\checkmark$ functional architectures. ${ }^{1}$ One subset of these, metal-organic polyhedral complexes, have proven useful in a range of applications, including molecular recognition, ${ }^{2}$ chirality sensing, ${ }^{3}$ gas separation, ${ }^{4}$ stabilization of reactive species, ${ }^{5}$ and catalysis. ${ }^{6}$ The strategy of subcomponent self-assembly ${ }^{7}$ allows the preparation of a variety of capsules with different shapes and sizes, which bind many different guests. ${ }^{8}$ Most such capsules contain cavities surrounded by aromatic panels. ${ }^{7 a-d}$ The elaboration of the cavity microenvironment, through incorporation of functional moieties, ${ }^{7 \mathrm{e}, \mathrm{f}}$ represents an attractive means by which specific substrate encapsulation might be achieved.

Azaphosphatranes, the conjugate acids of Verkade superbases, ${ }^{9}$ are attractive functional moieties for incorporation into the faces of tetrahedral capsules. Their polarized ${ }^{+} \mathrm{P}-\mathrm{H}$ groups enable them to be employed as catalysts for $\mathrm{CO}_{2}$ activation and lactide ring-opening polymerization. ${ }^{10}$ Although both of these applications benefit from the hydrogen-bond donor ability of the ${ }^{+} \mathrm{P}-\mathrm{H}$ group, their use as anion receptors has not been reported. Importantly, these cationic species can be rendered water-soluble via selection of a suitable counterion, potentially enabling their use as anion binders in water, the development of which has been identified as a key challenge in supramolecular chemistry. ${ }^{11}$

Anion recognition in water is intimately involved in many chemical, biological, and environmental processes. ${ }^{11}$ However, hydration of both the host and guest often hinders complex- ation. ${ }^{11 \mathrm{f}}$ Nonetheless, several synthetic anion receptors able to operate in water have been reported, employing hydrophobic effects, metal-anion coordination, $\mathrm{C}-\mathrm{H}$ hydrogen bonds, and halogen bonds. ${ }^{11 \mathrm{f}}$

Here we report a new azaphosphatrane-functionalized tetrahedron 1 (Scheme 1), assembled from cationic triamine

Scheme 1. Subcomponent Self-Assembly of Cage 1 in Acetonitrile

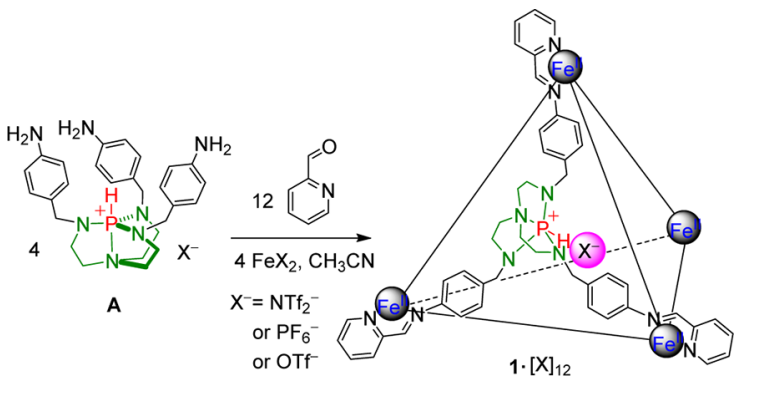

subcomponent $\mathbf{A}$. The design of $\mathbf{1}$ was based on the following four principles. First, the cationic azaphosphatranes together with the metal ions provide an overall +12 charge, offering a strong electrostatic driving force for anion binding. Second, the cationic framework also inductively increases the affinity of the ${ }^{+} \mathrm{P}-\mathrm{H}$ hydrogen bond donor for anionic species. ${ }^{12}$ Third, the sulfate counterion was chosen to maximize the water solubility of $\mathbf{1}$. Fourth, methylene groups between the phenyl rings and azaphosphatrane nitrogen atoms were introduced to enhance cage flexibility, enabling the cavity to fit a diverse array of anions.

We first prepared cage $\mathbf{1}$ as the bis(trifluoromethanesulfonyl)imide (triflimide, $\mathrm{Tf}_{2} \mathrm{~N}^{-}$), hexafluorophosphate $\left(\mathrm{PF}_{6}^{-}\right)$, and trifluoromethanesulfonate (triflate, $\mathrm{TfO}^{-}$) salts, all of which were soluble in acetonitrile (Scheme 1). The chloride salt of subcomponent A was obtained in four steps (Scheme S1). The $\mathrm{Cl}^{-}$of A readily exchanged with $\mathrm{Tf}_{2} \mathrm{~N}^{-}, \mathrm{PF}_{6}^{-}$, or $\mathrm{TfO}^{-}$via anion metathesis. The subsequent reaction of $\mathbf{A}$ (4 equiv) with the corresponding $\mathrm{FeX}_{2}$ salt (4 equiv) and 2-formylpyridine (12 equiv) in acetonitrile gave a single product with one azaphosphatrane capping each face (Scheme 1). Products were characterized by NMR and mass spectrometry (Figures S1-S36).

Received: March 24, 2017

Published: May 2, 2017 
${ }^{19}$ F NMR spectra (Figures S5, S17, and S29) indicated the encapsulation of one anion inside the cavity, in slow exchange on the NMR time scale with the external anions.

Single-crystal X-ray diffraction confirmed the structure of $\mathbf{1}$ in the solid state. As shown in Figure 1, 1 has a face-capped

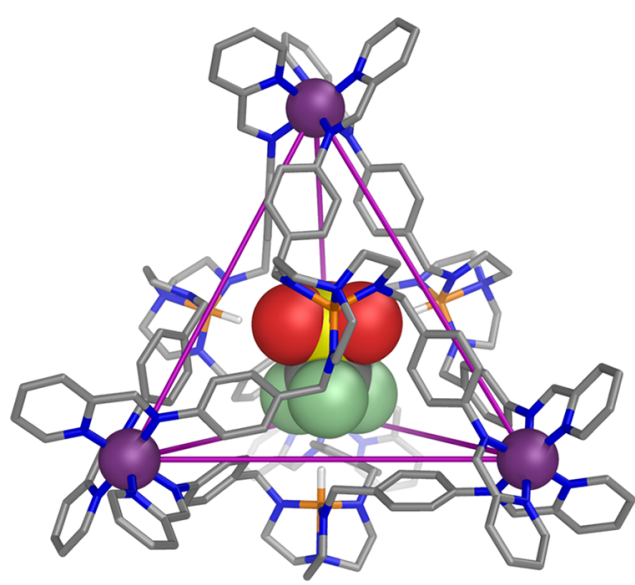

Figure 1. Crystal structure of $\mathrm{TfO}^{-} \subset 1$, which shows a $T$-symmetric cage. Disorder, unbound counterions, non-P-bound hydrogen atoms, and solvents are omitted for clarity.

tetrahedral framework with approximate $T$-symmetry. Both enantiomers $(\Delta \Delta \Delta \Delta$ and $\Lambda \Lambda \Lambda \Lambda)$ are present in the unit cell. The ${ }^{+} \mathrm{P}-\mathrm{H}$ groups of the azaphosphatrane units point inward into the cavity, where a disordered $\mathrm{TfO}^{-}$is encapsulated. The $\mathrm{Fe}^{\mathrm{II}}$ centers are separated by an average of $14.7 \AA$, and the volume of the central cavity approximates $166 \AA^{3}$ (51\% occupancy for $\mathrm{TfO}^{-}$, Figure S72).

We then attempted the preparation of a water-soluble cage by employing $\mathrm{SO}_{4}{ }^{2-}$ counterions. ${ }^{13}$ The initial $\mathrm{Cl}^{-}$of $\mathbf{A}$ was exchanged for $\mathrm{SO}_{4}{ }^{2-}$ (Scheme S2). However, the subsequent reaction of the sulfate salt of $\mathbf{A}$ (4 equiv) with $\mathrm{FeSO}_{4}$ (4 equiv) and 2 -formylpyridine ( 12 equiv) in water failed to give the expected cage complex (Figure S37). We infer that the hydrophilic character of $\mathrm{SO}_{4}{ }^{2-}$ prevents it from acting as a template for the formation of $1 .{ }^{14}$ Therefore, a series of other anions with different shapes and volumes, listed in Figure 2, were added to the aqueous reaction mixture to investigate their template effects ( 1 equiv of anion was added in each case with regard to the final cage).

All of the anions listed in Figure 2, with volumes ranging from $35 \AA^{3}\left(\mathrm{I}^{-}\right)$to $219 \AA^{3}\left(\mathrm{CB}_{11} \mathrm{H}_{12}{ }^{-}\right)$, were observed to serve as competent templates for $\mathbf{1}$ in water, indicating that its cavity adapted readily to guests having different sizes and shapes.

Cage 1 manifested this adaptability in a novel way: for the smaller template anions, with volumes $\leq 53 \AA^{3}$, part of the population of 1 consisted of a $C_{3}$-symmetric isomer $\left(C_{3}-1\right)$ in which one of the azaphosphatrane ${ }^{+} \mathrm{P}-\mathrm{H}$ groups was oriented away from the inner cavity (exo) with the other three pointed inward (endo). A $T$-symmetric isomer ( $T$-1), containing four endo ${ }^{+} \mathrm{P}-\mathrm{H}$ groups, constituted the other part of the population. For the larger anionic templates, having volumes $\geq 55 \AA^{3}$, the $T$ symmetric isomer $(T-1)$ of the cage was observed exclusively.

The ${ }^{1} \mathrm{H}$ NMR spectra of 1 templated by $\mathrm{BF}_{4}{ }^{-}, \mathrm{NO}_{3}{ }^{-}$, or $\mathrm{I}^{-}$in water thus show five sets of ligand signals (Figures S38) in which one set belongs to $T-1$, while the other four sets in a 1:1:1:1 ratio belong to $C_{3}-1$ (for full structural assignment of $C_{3}-1$, see Figure S43). The corresponding ${ }^{31} \mathrm{P}$ NMR spectra exhibit three peaks, one for $T-1$ and two in a 3:1 ratio for $C_{3}-1$ (Figure S39). The two

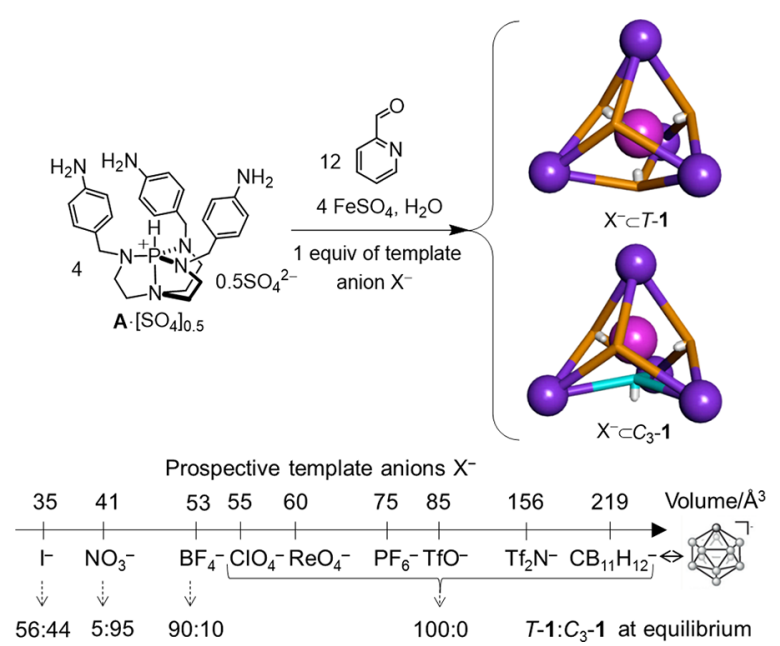

Figure 2. Schematic representation of the two cage isomers $\mathrm{X}^{-} \subset T-1$ and $\mathrm{X}^{-} \subset C_{3}-1$ obtained by aqueous self-assembly in the presence of 1 equiv of template anion. The cage faces colored orange represent endoazaphosphatrane ligands, with ${ }^{+} \mathrm{P}-\mathrm{H}$ pointing inward, while the cyan face represents exo ${ }^{+} \mathrm{P}-\mathrm{H}$.

cage isomers were observed to interconvert, taking at least 2 weeks at $298 \mathrm{~K}$ to reach equilibrium, as monitored by both ${ }^{1} \mathrm{H}$ and ${ }^{31} \mathrm{P}$ NMR.

For the self-assembly with $\mathrm{NO}_{3}{ }^{-}$as a template, gradual conversion from $T-1$ to $C_{3}-1$ was observed, with the ratio changing from 58:42 at $24 \mathrm{~h}$ to $10: 90$ at $215 \mathrm{~h}$ (Figures 3 and $540-$

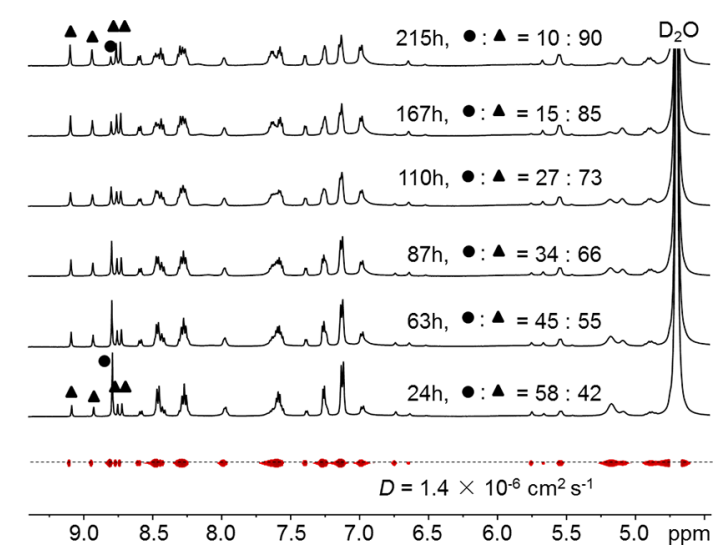

Figure 3. Time evolution of the ratio between $\mathrm{NO}_{3}{ }^{-} \subset T-\mathbf{1} \cdot\left[\mathrm{SO}_{4}\right]_{5.5}(\bullet)$ and $\mathrm{NO}_{3}{ }^{-} \subset \mathrm{C}_{3} \mathbf{- 1} \cdot\left[\mathrm{SO}_{4}\right]_{5.5}(\boldsymbol{\Delta})$ at $298 \mathrm{~K}$ by monitoring the integration of the corresponding imine peaks in the ${ }^{1} \mathrm{H}$ NMR spectra $\left(\mathrm{D}_{2} \mathrm{O}, 500 \mathrm{MHz}\right.$, $298 \mathrm{~K})$. DOSY NMR indicated that the two species diffuse at the same rate.

S42). This observation indicates that the initially formed mixture between $\mathrm{NO}_{3}{ }^{-} \subset T-1$ and $\mathrm{NO}_{3}{ }^{-} \subset C_{3}-1$ is kinetically metastable. The ratio further shifted to a constant value of 5:95 after 2 weeks at $298 \mathrm{~K}$ (Figure S43), corresponding to a Gibbs free energy change $(\Delta G)$ of $7.3 \mathrm{~kJ} \mathrm{~mol}^{-1}$ in favor of the $C_{3}$ isomer. The free energy of activation $\left(\Delta G^{\ddagger}\right)$ from $\mathrm{NO}_{3}{ }^{-} \subset T$-1 to $\mathrm{NO}_{3}{ }^{-} \subset C_{3}-1$ was calculated to be $105 \mathrm{~kJ} \mathrm{~mol}^{-1}$ at $298 \mathrm{~K}$ (Supporting Information section 2.4 .4 and Figure S68).

In the cases of $\mathrm{BF}_{4}^{-}$(Figures S51 and S52) and $\mathrm{I}^{-}$(Figures S54 and S55), T-1 was observed to be thermodynamically favored over $C_{3}-1$, giving equilibrium ratios of $90: 10$ and $56: 44$. These values correspond to $\Delta G$ differences of 5.4 and $0.64 \mathrm{~kJ} \mathrm{~mol}^{-1}$, respectively. The $\Delta G^{\ddagger}$ values at $298 \mathrm{~K}$ for the conversion from 
$\mathrm{X}^{-} \subset T-1$ to $\mathrm{X}^{-} \subset C_{3}-1$ were 110 and $107 \mathrm{~kJ} \mathrm{~mol}^{-1}$, for $\mathrm{X}^{-}=\mathrm{BF}_{4}^{-}$ and $\mathrm{I}^{-}$, respectively (Figures S69 and S70), similar to the value obtained for $\mathrm{NO}_{3}{ }^{-}$. Considering that these kinetic data are close to the previously reported energy barriers for interconversion between analogous diastereomers of $\mathrm{M}_{4} \mathrm{~L}_{6}$ cages (ca. $102 \mathrm{~kJ}$ $\left.\mathrm{mol}^{-1}\right),{ }^{15}$ and noting that no disassembled products were observed during the conversion, we hypothesize that the face inversion occurs via disruption of $\mathrm{Fe}^{\mathrm{II}}-\mathrm{N}$ linkages, as with $\mathrm{M}_{4} \mathrm{~L}_{6}$ cage diastereomer interconversion, ${ }^{15}$ as opposed to a reconfiguration at the azaphosphatrane units, whose $\mathrm{P}-\mathrm{N}$ bonds are inferred to be stronger. ${ }^{9,16}$ Iminopyridine moieties thus detach from $\mathrm{Fe}^{\mathrm{II}}$, allowing the azaphosphatrane to pirouette $180^{\circ}$ (Figure S71), whereby the cage framework maintains a degree of structural integrity throughout the rearrangement. ${ }^{17}$

Based on the crystal structure of $\mathrm{TfO}^{-} \subset 1$ in Figure 1, we prepared an MM3 model of $\mathrm{NO}_{3}{ }^{-} \subset C_{3}-1$ using the SCIGRESS software package (Figure 4). ${ }^{18}$ The trigonal planar $\mathrm{NO}_{3}{ }^{-}$is

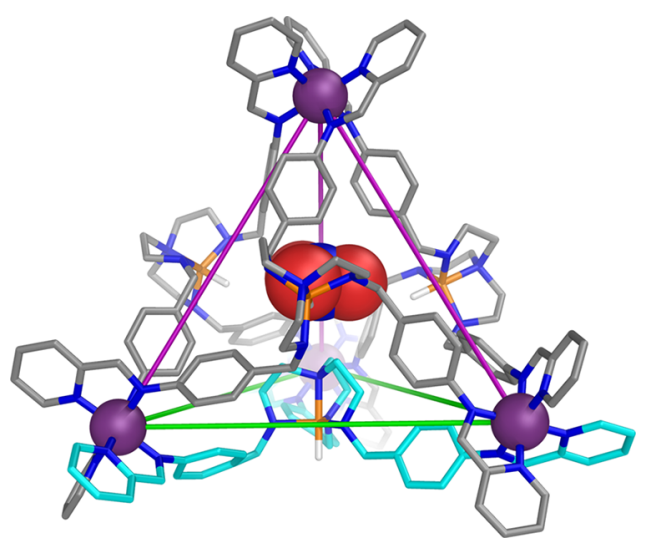

Figure 4. MM3-optimized molecular model of $\mathrm{NO}_{3}{ }^{-} \subset C_{3}-1$ based on the crystal structure of $\mathrm{TfO}^{-} \subset 1$ shown in Figure 1. Non-P-bound hydrogen atoms are omitted for clarity. The exo-azaphosphatrane ligand is colored cyan.

centrally bound by the three endo ${ }^{+} \mathrm{P}-\mathrm{H}$ groups. The methylene groups of the exo-azaphosphatrane occupy the rest of the cavity. The volume of the preorganized planar cavity approximates $59 \AA^{3}$ (69\% occupancy for $\mathrm{NO}_{3}^{-}$, Figure S72), significantly smaller than that of $\mathrm{TfO}^{-} \subset T-1\left(166 \AA^{3}\right)$. This model also suggests that the shape-fit between $\mathrm{C}_{3}-1$ and $\mathrm{NO}_{3}{ }^{-}$may account for the greater favoring by this anion of this isomer, as compared to $\mathrm{BF}_{4}{ }^{-}$(Figure S53) or I- (Figure S56).

${ }^{1} \mathrm{H},{ }^{13} \mathrm{C}$, and ${ }^{31} \mathrm{P}$ NMR spectra of 1 templated by $\mathrm{ClO}_{4}{ }^{-}, \mathrm{ReO}_{4}{ }^{-}$, $\mathrm{PF}_{6}^{-}, \mathrm{TfO}^{-}, \mathrm{Tf}_{2} \mathrm{~N}^{-}$, or $\mathrm{CB}_{11} \mathrm{H}_{12}{ }^{-}$in water show only one set of ligand signals (Figures S57-S60), consistent with the exclusive formation of $T-\mathbf{1}$. The ${ }^{1} \mathrm{H}-{ }^{19} \mathrm{~F}$ HOESY spectra of the $\mathrm{TfO}^{-}$and $\mathrm{PF}_{6}{ }^{-}$adducts of $T-\mathbf{1}$ exhibited strong NOE correlations between the $\mathrm{F}$ atoms of the encapsulated guest and the ${ }^{+} \mathrm{P}-\mathrm{H}$ of the azaphosphatranes, underlining the hydrogen bonding interactions (Figures S61, S66, and S67).

Although the cage was unstable in the absence of a template anion, competitive guest exchange offers a way of measuring the relative binding affinities of the different anions. We first chose $\mathrm{TfO}^{-} \subset \mathbf{1} \cdot\left[\mathrm{SO}_{4}\right]_{5.5}$ as the reference and monitored the decrease of the encapsulated $\mathrm{TfO}^{-}$and increase of the free $\mathrm{TfO}^{-}$by ${ }^{19} \mathrm{~F} \mathrm{NMR}$ upon addition of a competitive anion. Results showed that the binding affinities of $\mathrm{PF}_{6}^{-}, \mathrm{ReO}_{4}^{-}$, and $\mathrm{ClO}_{4}^{-}$were $17,1.9$, and 0.028 , respectively, relative to that of $\mathrm{TfO}^{-}$(Figures S73-S75). No obvious $\mathrm{TfO}^{-}$displacement was observed upon addition of $\mathrm{NO}_{3}{ }^{-}, \mathrm{BF}_{4}{ }^{-}, \mathrm{I}^{-}, \mathrm{Tf}_{2} \mathrm{~N}^{-}$, or $\mathrm{CB}_{11} \mathrm{H}_{12}{ }^{-19}$ We thus chose $\mathrm{Tf}_{2} \mathrm{~N}^{-} \subset \mathbf{1}$.
$\left[\mathrm{SO}_{4}\right]_{5.5}$ as the reference to determine the hierarchy of binding affinities of these latter anions. We observed by ${ }^{1} \mathrm{H}$ NMR that 1.7 equiv of $\mathrm{CB}_{11} \mathrm{H}_{12}{ }^{-}$completely displaced the encapsulated $\mathrm{Tf}_{2} \mathrm{~N}^{-}$ (Figure S76), while a larger excess ( $>6$ equiv) of $\mathrm{BF}_{4}{ }^{-}$or $\mathrm{I}^{-}$was needed for $\mathrm{Tf}_{2} \mathrm{~N}^{-}$displacement, with $\mathrm{BF}_{4}{ }^{-}$binding more strongly than $\mathrm{I}^{-}$(Figures $\mathrm{S} 77$ and S78). $\mathrm{NO}_{3}^{-}$(12 equiv) was unable to displace the bound $\mathrm{Tf}_{2} \mathrm{~N}^{-}$. Combining these results, we observe the following anion binding hierarchy in water: $\mathrm{PF}_{6}{ }^{-}>\mathrm{ReO}_{4}{ }^{-}>$ $\mathrm{TfO}^{-}>\mathrm{ClO}_{4}^{-}>\mathrm{CB}_{11} \mathrm{H}_{12}^{-}>\mathrm{Tf}_{2} \mathrm{~N}^{-}>\mathrm{BF}_{4}^{-}>\mathrm{I}^{-}>\mathrm{NO}_{3}^{-}$.

Although tetrahedron 1 templated by $\mathrm{BF}_{4}{ }^{-}$was observed in two distinct isomeric forms $\left(T-1 \rightleftharpoons C_{3}-1\right)$, we noted during the titration of $\mathrm{BF}_{4}^{-}$into $\mathrm{Tf}_{2} \mathrm{~N}^{-} \subset T-1$ that only $\mathrm{BF}_{4}{ }^{-} \subset T-1$ was observed within $5 \mathrm{~h} . \mathrm{BF}_{4}{ }^{-} \subset C_{3}-1$ appeared only thereafter, indicating a short-term shape memory effect (Figure 5). Further

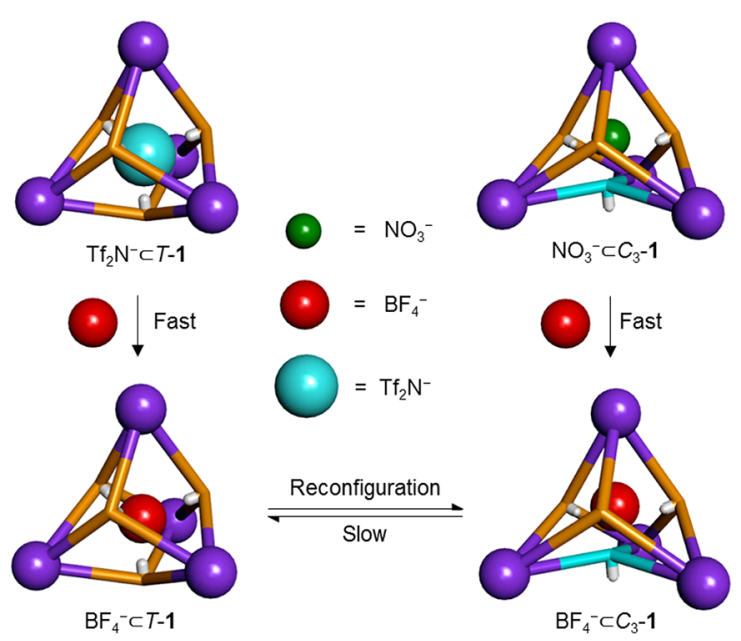

Figure 5. Schematic representation of two successive processes: fast guest displacement of $\mathrm{Tf}_{2} \mathrm{~N}^{-}$or $\mathrm{NO}_{3}{ }^{-}$by $\mathrm{BF}_{4}^{-}$, giving rise to a shape memory phenomenon, followed by slow isomeric reconfiguration.

experiments showed that, after addition of $\mathrm{BF}_{4}{ }^{-}$(2 equiv) to 5:95 ratio of $\mathrm{NO}_{3}{ }^{-} \subset \mathrm{C}-\mathbf{1}: \mathrm{NO}_{3}{ }^{-} \subset C_{3}-1$ in solution, a 5:95 ratio of $\mathrm{BF}_{4}{ }^{-} \subset T-1 / \mathrm{BF}_{4}{ }^{-} \subset C_{3}-1$ was observed immediately following the anion displacement (Figure $\mathrm{S} 79$ ). $\mathrm{BF}_{4}{ }^{-} \subset C_{3}-1$ then gradually converted to $\mathrm{BF}_{4}{ }^{-} \subset T-1$. These results indicate the occurrence of two successive processes: rapid guest displacement, with maintenance of the initial ratio of cage diastereomers, followed by slower $\mathrm{BF}_{4}{ }^{-}$templated isomeric reconfiguration.

Taking advantage of the larger population of $\mathrm{BF}_{4}{ }^{-} \subset C_{3}-1$ (95\%) following anion exchange from $\mathrm{NO}_{3}{ }^{-} \subset 1$, we were able to observe heteronuclear $\mathrm{NOE}$ correlations between the bound $\mathrm{BF}_{4}{ }^{-}$and the methylene protons of the exo-azaphosphatrane of $\mathrm{BF}_{4}{ }^{-} \subset C_{3}-1$ in ${ }^{1} \mathrm{H}-{ }^{19} \mathrm{~F}$ HOESY spectrum (Figure S80). These correlations provide important structural evidence for the exo configuration of one face of $C_{3}-1$, but they could not be observed directly in the $\mathrm{BF}_{4}{ }^{-}$-templated assembly, wherein the population of $\mathrm{BF}_{4}{ }^{-} \subset C_{3}-1$ constituted less than $25 \%$.

In summary, this study has demonstrated the feasibility of introducing azaphosphatranes into polyhedral complexes using subcomponent self-assembly and also shown the utility of azaphosphatranes as anion binding moieties. The designed flexibility of the structures reported herein enables the aqueous binding of anions with volumes ranging from 35 to $219 \AA^{3}$ via hydrogen bonding and electrostatic interactions. Structural adaptation of the cage framework was observed in response to the sizes and shapes of template anions, enabling the selective formation of either a $T$ - or a $C_{3}$-symmetric cage framework, which 
are capable of interconversion. A shape memory phenomenon was observed during guest displacement, due to its faster kinetics compared to those of framework reconfiguration. Future work will seek to use this tailored cage or one of its derivatives as a catalyst, benefiting from the internally oriented azaphosphatrane $\mathrm{H}$-bond donors, for instance, for $\mathrm{CO}_{2}$ conversion.

\section{ASSOCIATED CONTENT}

\section{S Supporting Information}

The Supporting Information is available free of charge on the ACS Publications website at DOI: 10.1021/jacs.7b02950.

Experimental details (PDF)

Crystallographic data for $\mathrm{TfO}^{-} \subset 1$ (CCDC 1529220) (CIF)

\section{AUTHOR INFORMATION}

\section{Corresponding Authors}

*alexandre.martinez@centrale-marseille.fr

*jrn34@cam.ac.uk

ORCID

Alexandre Martinez: 0000-0002-6745-5734

Jonathan R. Nitschke: 0000-0002-4060-5122

Notes

The authors declare no competing financial interest.

\section{ACKNOWLEDGMENTS}

This work was supported by the UK Engineering and Physical Sciences Research Council (EPSRC EP/M008258/1). The authors thank the Department of Chemistry NMR facility, University of Cambridge for performing some NMR experiments, and the EPSRC UK National Mass Spectrometry Facility at Swansea University for carrying out high-resolution mass spectrometry. D.Z. acknowledges a grant from the China Scholarship Council, Accueil Doc Bursary from France RhôneAlpes Region, and Enveloppe Attractivité Fellowship from ENSLyon for Ph.D. studies.

\section{REFERENCES}

(1) (a) Wang, W.; Wang, Y. X.; Yang, H. B. Chem. Soc. Rev. 2016, 45, 2656. (b) Cook, T. R.; Stang, P. J. Chem. Rev. 2015, 115, 7001. (c) Krieg, E.; Bastings, M. M. C.; Besenius, P.; Rybtchinski, B. Chem. Rev. 2016, 116, 2414. (d) He, Z. F.; Jiang, W.; Schalley, C. A. Chem. Soc. Rev. 2015, 44, 779. (e) Mauro, M.; Aliprandi, A.; Septiadi, D.; Kehr, N. S.; De Cola, L. Chem. Soc. Rev. 2014, 43, 4144. (f) Yang, L. L.; Tan, X. X.; Wang, Z. Q.; Zhang, X. Chem. Rev. 2015, 115, 7196. (g) Yu, G. C.; Jie, K. C.; Huang, F. H. Chem. Rev. 2015, 115, 7240.

(2) (a) Chan, A. K. W.; Lam, W. H.; Tanaka, Y.; Wong, K. M. C.; Yam, V. W.W.Proc. Natl. Acad. Sci. U. S. A. 2015, 112, 690. (b) Bloch, W. M.; Abe, Y.; Holstein, J.J.; Wandtke, C. M.; Dittrich, B.; Clever, G. H.J. Am. Chem. Soc. 2016, 138, 13750. (c) Zhang, Z.; Kim, D. S.; Lin, C. Y.; Zhang, H. C.; Lammer, A. D.; Lynch, V. M.; Popov, I.; Miljanic, O. S.; Anslyn, E. V.; Sessler, J. L. J. Am. Chem. Soc. 2015, 137, 7769. (d) Custelcean, R.; Bonnesen, P. V.; Duncan, N. C.; Zhang, X. H.; Watson, L. A.; Van Berkel, G.; Parson, W. B.; Hay, B. P. J. Am. Chem. Soc. 2012, 134, 8525. (e) Samanta, S. K.; Moncelet, D.; Briken, V.; Isaacs, L. J. Am. Chem. Soc. 2016, 138, 14488. (f) Bruns, C. J.; Fujita, D.; Hoshino, M.; Sato, S.; Stoddart, J. F.; Fujita, M. J. Am. Chem. Soc. 2014, 136, 12027.

(3) (a) You, L.; Berman, J. S.; Anslyn, E. V. Nat. Chem. 2011, 3, 943. (b) Albrecht, M.; Isaak, E.; Baumert, M.; Gossen, V.; Raabe, G.; Frohlich, R. Angew. Chem., Int. Ed. 2011, 50, 2850.

(4) (a) Wu, Y.; Zhou, X. P.; Yang, J. R.; Li, D. Chem. Commun. 2013, 49, 3413. (b) Chen, T. H.; Popov, I.; Kaveevivitchai, W.; Chuang, Y. C.; Chen, Y. S.; Daugulis, O.; Jacobson, A. J.; Miljanic, O. S. Nat. Commun. 2014, 5, 5131.
(5) Ren, H. F.; Huang, Z. H.; Yang, H.; Xu, H. P.; Zhang, X. ChemPhysChem 2015, 16, 523.

(6) (a) Yoshizawa, M.; Tamura, M.; Fujita, M. Science 2006, 312, 251. (b) Cakmak, Y.; Erbas-Cakmak, S.; Leigh, D. A. J. Am. Chem. Soc. 2016, 138, 1749. (c) Kaphan, D. M.; Levin, M. D.; Bergman, R. G.; Raymond, K. N.; Toste, F. D. Science 2015, 350, 1235. (d) Omagari, T.; Suzuki, A.; Akita, M.; Yoshizawa, M.J. Am. Chem. Soc. 2016, 138, 499. (e) Cullen, W.; Misuraca, M. C.; Hunter, C. A.; Williams, N. H.; Ward, M. D. Nat. Chem. 2016, 8, 231. (f) Howlader, P.; Das, P.; Zangrando, E.; Mukherjee, P. S. J. Am. Chem. Soc. 2016, 138, 1668.

(7) (a) Ronson, T. K.; Zarra, S.; Black, S. P.; Nitschke, J. R. Chem. Commun. 2013, 49, 2476. (b) Zhou, X. P.; Wu, Y.; Li, D. J. Am. Chem. Soc. 2013, 135, 16062. (c) Sham, K. C.; Yiu, S. M.; Kwong, H. L. Inorg. Chem. 2013, 52, 5648. (d) Ren, D. H.; Qiu, D.; Pang, C. Y.; Li, Z. J.; Gu, Z. G. Chem. Commun. 2015, 51, 788. (e) Yi, S.; Brega, V.; Captain, B.; Kaifer, A. E. Chem. Commun. 2012, 48, 10295. (f) Young, M. C.; Holloway, L. R; Johnson, A. M.; Hooley, R. J. Angew. Chem., Int. Ed. 2014, 53, 9832. (g) Bunzen, H.; Nonappa; Kalenius, E.; Hietala, S.; Kolehmainen, E. Chem. - Eur. J. 2013, 19, 12978. (h) Domer, J.; Slootweg, J. C.; Hupka, F.; Lammertsma, K.; Hahn, F. E. Angew. Chem., Int. Ed. 2010, 49, 6430. (i) Lewing, D.; Koppetz, H.; Hahn, F. E. Inorg. Chem. 2015, 54, 7653.

(8) (a) Frischmann, P. D.; Kunz, V.; Wurthner, F. Angew. Chem., Int.Ed. 2015, 54, 7285. (b) Roukala, J.; Zhu, J. F.; Giri, C.; Rissanen, K.; Lantto, P.; Telkki, V. V. J. Am. Chem. Soc. 2015, 137, 2464. (c) Luo, D.; Zhou, X. P.; Li, D. Angew. Chem., Int. Ed. 2015, 54, 6190.

(9) Lensink, C.; Xi, S. K.; Daniels, L. M.; Verkade, J. G. J. Am. Chem. Soc. $1989,111,3478$.

(10) (a) Chatelet, B.; Joucla, L.; Dutasta, J. P.; Martinez, A.; Szeto, K. C.; Dufaud, V. J. Am. Chem. Soc. 2013, 135, 5348. (b) Zhang, D. W.; Jardel, D.; Peruch, F.; Calin, N.; Dufaud, V.; Dutasta, J. P.; Martinez, A.; Bibal, B. Eur. J. Org. Chem. 2016, 2016, 1619.

(11) (a) Busschaert, N.; Caltagirone, C.; Van Rossom, W.; Gale, P. A. Chem. Rev. 2015, 115, 8038. (b) Ballester, P. Chem. Soc. Rev. 2010, 39, 3810. (c) Zhou, Y.; Zhang, J. F.; Yoon, J. Chem. Rev. 2014, 114, 5511. (d) Katayev, E. A.; Kolesnikov, G. V.; Sessler, J. L. Chem. Soc. Rev. 2009, 38, 1572. (e) Sokkalingam, P.; Shraberg, J.; Rick, S. W.; Gibb, B. C. J.Am. Chem. Soc. 2016, 138, 48. (f) Langton, M. J.; Serpell, C. J.; Beer, P. D. Angew. Chem., Int.Ed. 2016, 55, 4629. (g) Kang, S. O.; Llinares, J. M.; Day, V.W.; Bowman-James, K. Chem. Soc. Rev. 2010, 39, 3980. (h) Jo, J.; Olasz, A.; Chen, C. H.; Lee, D. J. Am. Chem. Soc. 2013, 135, 3620. (i) Kubik, S. Chem. Soc. Rev. 2010, 39, 3648. (j) Wang, Q. Q.; Day, V. W.; BowmanJames, K. Angew. Chem., Int. Ed. 2012, 51, 2119. (k) Fabbrizzi, L.; Poggi, A. Chem. Soc. Rev. 2013, 42, 1681. (1) Lisbjerg, M.; Valkenier, H.; Jessen, B. M.; Al-Kerdi, H.; Davis, A. P.; Pittelkow, M. J. Am. Chem. Soc. 2015, 137, 4948.

(12) Ayme, J. F.; Beves, J. E.; Campbell, C. J.; Gil-Ramirez, G.; Leigh, D. A.; Stephens, A. J. J. Am. Chem. Soc. 2015, 137, 9812.

(13) Bolliger, J. L.; Ronson, T. K.; Ogawa, M.; Nitschke, J. R. J. Am. Chem. Soc. 2014, 136, 14545.

(14) (a) Custelcean, R. Chem. Commun. 2013, 49, 2173. (b) Pandurangan, K.; Kitchen, J. A.; Blasco, S.; Boyle, E. M.; Fitzpatrick, B.; Feeney, M.; Kruger, P. E.; Gunnlaugsson, T. Angew. Chem., Int. Ed. 2015, 54, 4566.

(15) Meng, W.; Clegg, J. K.; Thoburn, J. D.; Nitschke, J. R. J. Am. Chem. Soc. 2011, 133, 13652.

(16) Verkade, J. G. Acc. Chem. Res. 1993, 26, 483.

(17) Castilla, A. M.; Ousaka, N.; Bilbeisi, R. A.; Valeri, E.; Ronson, T. K.; Nitschke, J. R. J. Am. Chem. Soc. 2013, 135, 17999.

(18) Stewart, J. J. P. SCIGRESS, version 2.9.0; Fujitsu Limited: United States, 2009.

(19) Addition of $\mathrm{Tf}_{2} \mathrm{~N}^{-}$and $\mathrm{CB}_{11} \mathrm{H}_{12}{ }^{-}$resulted in partial precipitation of the cage. One equivalent of $\mathrm{Tf}_{2} \mathrm{~N}^{-}$precipitates about $9 \%$ of the cage. 